\title{
A PROSPECTIVE COMPARATIVE STUDY TO ASSESS THE IMPACT OF MATERNAL BODY MASS INDEX ON OBSTETRIC OUTCOME
}

\begin{tabular}{ll}
$\begin{array}{l}\text { Dr. Prashant Kumar } \\
\text { Meena }\end{array}$ & $\begin{array}{l}\text { Resident Doctor, Department of General medicine, Sardar Patel Medical } \\
\text { College, Bikaner }\end{array}$ \\
\hline Dr. Rohitash Kularia & $\begin{array}{l}\text { Associate professor, Department of General medicine, Sardar Patel } \\
\text { Medical College, Bikaner }\end{array}$ \\
\hline Dr.Subash Chandra & $\begin{array}{l}\text { Associate professor, Department of General medicine, Sardar Patel } \\
\text { Medical College, Bikaner }\end{array}$ \\
\hline Dr. Anita Sharma* & $\begin{array}{l}\text { Associate professor,Department of Obstetrics and Gynecology, S. P. } \\
\text { Medical College, Bikaner *Corresponding Author }\end{array}$ \\
\hline
\end{tabular}

ABSTRACT Background- The prevalence of obesity is increasing steadily even in developing countries as economic prosperity has increased. In developing countries like India, overweight and obesity often co-exist with undernutrition. Methods- Hospital based prospective comparative study was conducted on 100 women in each group including normal, high and low maternal BMI. Result- The average weight gain during pregnancy $7.42 \pm 2.68 \mathrm{~kg}$, in underweight category it was $6.32 \pm 2.98 \mathrm{~kg}$ while it was $8.36 \pm 2.68 \mathrm{~kg}$ in normal BMI category. Postpartum complications like PPH were insignificantly higher in overweight category. Conclusion -Maternal BMI shows strong associations with pregnancy complications. Attempt should be made to prevent obesity in women of childbearing age and encourage weight loss to attain ideal weight before pregnancy.

KEYWORDS : BMI, Obese, Maternal out come.

\section{INTRODUCTION}

Maternal body mass index (BMI) is one of the most important predictor of nutritional status of pregnant lady. Both nutritional intake and maternal weight are modifiable factors which can influence pregnancy outcome. Either underweight or overweight both can have a signifi cant impact on outcome of pregnancy.

Overweight and obesity in pregnant women are associated with increased risk of miscarriages, gestational diabetes, thromboembolism, hyperlipidemia, gestational hypertension and preeclampsia, recurrent infections and prolonged pregnancy.

Worldwide there has been alarming increase in the incidence of obesity and overweight, particularly in the past two to three decades. In the latest report, the WHO has indicated that approximately 1.6 billion adults are overweight and around 400 million are obese. Obesity as thus becomes a major contributor for global burden of chronic diseases and disabilities. $^{2}$

Low maternal BMI showing imbalance between energy intake and energy expenditure, might be a general marker of minimal tissue reserve. A malnourished mother gives birth to an undernourished infant who fails to thrive.

\section{MATERIAL AND METHODS}

Study design: Hospital based prospective comparative study.

Study population: Women attending antenatal OPD in first trimester.

Sampling Method: Random sampling Inclusion Criteria:

1. All pregnant women including those with normal, low and high BMI attending antenatal OPD in first trimester and not coming under exclusion criteria.

2. Singleton pregnancies

3. Patient willing to give consent
Exclusion Criteria:

1. Pregnancies with multiple gestation like twins, triplets

2. All cases of pregnancies with chronic medical illness like diabetes, chronic hypertension, bronchial asthma, cancer or patient on any drug therapy.

3. Pregnancies associated with diagnosed congenital malformations and intrauterine dead fetus

Data Collection: After taking written and informed consent and fulfilling inclusion criteria, women attending antenatal OPD in first trimester were included in the study. Their weight was measured (in kilograms) without shoes. Subjects were made to stand erect on the floor barefoot with both ankles together and parallel to each other to note their height (in meters) with the head of the patient held in such a position that the line joining the tragus and outer canthus of eye were in a horizontal plane (Frankfurts Plane) such that the individual was standing straight next to the wall with the heels, buttocks, shoulders and occiput touching the wall. 3 comparative groups of 100 women each were studied.

- Underweight group- 100 antenatal patients with low BMI $(<18.5 \mathrm{~kg} / \mathrm{m} 2)$

- Normal weight group- 100 antenatal patients with normal BMI (18.5 kg $/ \mathrm{m} 2-24.99 \mathrm{~kg} / \mathrm{m} 2)$

- Overweight group- 100 antenatal patients with high BMI (equal to or $>25 \mathrm{~kg} / \mathrm{m} 2$ )

Data Ānalysis:

To collect required information from eligible patients, a prestructured pre-tested proforma was used. Data was analyzed with the help of mean, standard deviation and $p$ value was calculated using $\mathrm{T}$ test and chi square test using primer software.

\section{RESULTS}

Table 1.Distribution of cases according to weight gain during pregnancy

\begin{tabular}{|c|c|c|c|}
\hline $\begin{array}{c}\text { Weight Gain during } \\
\text { Pregnancy (kg) }\end{array}$ & $\begin{array}{c}\text { Over } \\
\text { weight }\end{array}$ & $\begin{array}{c}\text { Normal } \\
\text { Weight }\end{array}$ & $\begin{array}{c}\text { Under } \\
\text { weight }\end{array}$ \\
\hline Mean & 7.42 & 8.36 & 6.32 \\
\hline SD & 2.68 & 2.68 & 2.98 \\
\hline p value & \multicolumn{3}{|c|}{0.01 ( Significant) } \\
\hline
\end{tabular}


Table no. 1 shows that in overweight category, average weight gain during pregnancy was $7.42 \pm 2.68 \mathrm{~kg}$, in underweight category it was $6.32 \pm 2.98 \mathrm{~kg}$ while it was $8.36 \pm 2.68 \mathrm{~kg}$ in normal BMI category. On comparing the weight gain in all the three groups, the difference was statistically highly significant $(p=0.01)$.

Table 2.Distribution of cases according to incidence of preeclampsia

\begin{tabular}{|c|c|c|c|c|c|c|}
\hline $\begin{array}{c}\text { Preeclam } \\
\text { psia }\end{array}$ & \multicolumn{2}{|c|}{ Overweight } & \multicolumn{2}{c|}{$\begin{array}{c}\text { Normal } \\
\text { Weight }\end{array}$} & \multicolumn{2}{c|}{ Underweight } \\
\cline { 2 - 7 } & No. & $\%$ & No. & $\%$ & No. & $\%$ \\
\hline Present & 18 & 18.00 & 8 & 8.00 & 3 & 3.00 \\
\hline Absent & 82 & 82.00 & 92 & 92.00 & 97 & 97.00 \\
\hline Total & 100 & 100 & 100 & 100 & 100 & 100.00 \\
\hline p value & \multicolumn{6}{|c|}{0.001 (Highly significant) } \\
\hline
\end{tabular}

Table no. 2 shows that preeclampsia complicated $18.00 \%$ of overweight pregnancies while it was $3.00 \%$ in underweight group and $8.00 \%$ in normal weight group. The difference was statistically highly significant $(\mathrm{p}=0.001)$.

Table 3.Distribution of cases according to incidence of postpartum hemorrhage

\begin{tabular}{|c|c|c|c|c|c|c|}
\hline Postpartum & Overweight & Normal Weight & \multicolumn{3}{|c|}{ Underweight } \\
\cline { 2 - 7 } Hemorrhage (PPH) & No. & $\%$ & No. & $\%$ & No. & $\%$ \\
\hline Present & 9 & 9.00 & 4 & 4.00 & 1 & 1.00 \\
\hline Absent & 91 & 91.00 & 96 & 96.00 & 99 & 99.00 \\
\hline Total & 100 & 100 & 100 & 100 & 100 & 100 \\
\hline p value & \multicolumn{6}{|c|}{$>05$ (Not Significant) } \\
\hline
\end{tabular}

Table no. 3 shows that percentage of $\mathrm{PPH}$ in overweight group is $9.00 \%$ as compared to $4 \%$ in normal weight group and $1.00 \%$ in underweight group. The difference was statistically not significant $(p>0.05)$.

\section{DISCUSSION}

The average weight gain during pregnancy was $7.42 \pm 2.68$ $\mathrm{kg}$, in underweight category it was $6.32 \pm 2.98 \mathrm{~kg}$ while it was $8.36 \pm 2.68 \mathrm{~kg}$ in normal BMI category. The difference was statistically highly significant $(p=0.01)$. This could be due to malnourishment, lack of adequate nutrition, minimal body reserves, lack of awareness, poverty, early age marriages which leads to less weight gain during pregnancy in underweight. Majority of women had weight gain in the range of 5.1 to $10 \mathrm{~kg}$. Similar results were shown by previous studies $^{3,4}$

Preeclampsia was more common in overweight group $(18.00 \%)$ as compared to normal $(8.00 \%)$ and underweight group $(3.00 \%)$ in our study. The difference was statistically significant $(p=0.001)$. It is because obesity is associated with low grade inflammation and endothelial activation. Endothelial activation plays an integral role in preeclampsia. In a study conducted by sohinee Bhattacharya et al,5 $14.7 \%$ of obese women developed pre-eclampsia.

PPH was more common in overweight group (9.00\%) as compared to normal weight $(4.00 \%)$ and underweight group $(1.00 \%)$. The difference was however statistically not significant. This could be due to increased chances of instumental delivery in obese patients causing vaginal laceration as well as atonicity of uterus.

\section{CONCLUSION}

Maternal BMI shows strong associations with pregnancy complications. Attempt should be made to prevent obesity in women of childbearing age and encourage weight loss to attain ideal weight before pregnancy.

\section{REFERENCES}

1. Kumar HSA, Chellamma VK. Effect of Maternal Body Mass Index on Pregnancy Outcome. Int J Sci Stud 2017;4(10):81-84.

2. Obesity: Preventing and managing the global epidemic. Report of a WHO consultation. World Health Organ Tech Rep Ser 2000;894:i-xii, 1-253

3. Abrams B, Altman SB, Pickett KE. Pregnancy weight gain: still controversial. American Journal of Clinical Nutrition. May 2000; 71:1223-1241.

4. Crane JM, White J, Murphy P, Burrage L, Hutchens D. The effect of gestational weight gain by body mass index on maternal and neonatal outcomes. J Obstet Gynaecol. Jan 2009;31:28-35.

5. Bhattacharya S, Campbell DM, Liston WA, Bhattacharya S. Effect of body mass index on pregnancy outcomes in nulliparous women delivering singleton babies. BMC Public Health. 2007;7:168 